\title{
Mampukah Kepemilikan Institusional Mempengaruhi Tax Avoidance?
}

\author{
Vina $^{1}$ \\ Estralita Trisnawati ${ }^{2}$ \\ Amrie Firmansyah ${ }^{3}$ \\ 1,2Fakultas Ekonomi dan Bisnis Universitas Tarumanegara, Indonesia \\ 3 Politeknik Keuangan Negara STAN, Indonesia \\ *Correspondences: vina.127201011@stu.untar.ac.id
}

\begin{abstract}
ABSTRAK
Pajak memiliki kontribusi besar bagi penerimaan negara. Namun, pajak bagi perusahaan merupakan pengurang atas laba yang diperoleh. Penelitian ini bertujuan untuk menguji secara empiris pengaruh intensitas persediaan, intensitas aset tetap, beban iklan terhadap tax avoidance dengan kepemilikan institusional sebagai variabel moderasi. Penelitian ini dilakukan pada sektor perusahaan konsumen primer yang terdaftar di IDX tahun 2016 - 2019. Sampel dipilih dengan menggunakan metode purposive sampling. Teknik analisis data menggunakan Moderated Regression Analysis (MRA). Hasil penelitian menunjukkan bahwa intensitas persediaan dan intensitas aset tetap berpengaruh positif terhadap tax avoidance. Beban iklan berpengaruh negatif terhadap tax avoidance. Kepemilikan institusional tidak dapat memoderasi pengaruh intensitas persediaan dan beban iklan terhadap tax avoidance, tapi kepemilikan institusional dapat memperkuat pengaruh intensitas aset tetap terhadap tax avoidance.
\end{abstract}

Kata Kunci: Intensitas Persediaan; Intensitas Aset Tetap; Beban Iklan; Kepemilikan Institusional; Tax Avoidance.

\section{Can Institutional Ownership Affect Tax Avoidance?}$$
\text { ABSTRACT }
$$

Taxes have a major contribution to state revenue. However, the tax for the company is a deduction from the profits earned. This study aims to empirically examine the effect of inventory intensity, fixed asset intensity, advertising expense on tax avoidance with institutional ownership as a moderating variable. This research was conducted in the primary consumer company sector listed on IDX in 2016 - 2019. The sample was selected using the purposive sampling method. The data analysis technique used Moderated Regression Analysis (MRA). The results showed that inventory intensity and fixed asset intensity had a positive effect on tax avoidance. Advertising expenses have a negative effect on tax avoidance. Institutional ownership cannot moderate the effect of inventory intensity and advertising expense on tax avoidance, but institutional ownership can strengthen the effect of fixed asset intensity on tax avoidance.

Keywords: Inventory Intensity; Fixed Asset Intensity; Advertising Expense; Tax Avoidance; Institutional Ownership.
\end{abstract}

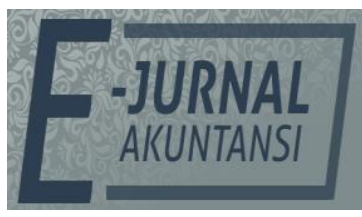

e-ISSN 2302-8556

Vol. 32 No. 1

Denpasar, Januari 2022

Hal. 139-154

DOI:

10.24843/EJA.2022.v32.i01.p10

PENGUTIPAN:

Vina, V., Trisnawati, E. \& Firmansyah, A. (2022). Mampukah Kepemilikan Institusional Mempengaruhi Tax Avoidance?. E-Jurnal Akuntansi, 32(1), 139-154

RIWAYAT ARTIKEL: Artikel Masuk: 9 November 2021 Artikel Diterima: 18 Januari 2022

Artikel dapat diakses : https://ojs.unud.ac.id/index.php/Akuntansi/index 


\section{PENDAHULUAN}

Pajak memiliki kontribusi yang besar untuk penerimaan negara, khususnya Pajak Pertambahan Nilai (insight.kontan.co.id, 2021). Negara menggunakan penerimaan pajak untuk pembiayaan negara dan pembangunan nasional dalam upaya mendukung kesejahteraan rakyat, baik dalam sarana pendidikan, pelayanan kesehatan, pemerataan pembangunan infrastruktur dan sarana serta prasarana lainnya (Muzakki \& Darsono, 2015). Tanpa adanya pajak, kehidupan suatu negara tidak akan berjalan dengan baik. Oleh karena itu, pajak dijadikan sebagai ujung tombak pembangunan suatu negara (Dirjen Pajak, 2015).

Pemerintah berupaya untuk mengoptimalkan penerimaan sektor pajak melalui program ekstensifikasi dan intensifikasi penerimaan pajak (Surat Direktorat Jenderal Pajak no. S-14/PJ.7/2003, 2003). Namun, optimalisasi penerimaan pajak suatu negara seringkali menemukan banyak kendala. Salah satunya adalah praktik penghindaran pajak atau tax avoidance. Berbanding terbalik dengan pemerintah, sebagian besar perusahaan akan melakukan perencanaan pajak dengan tujuan untuk mengurangi pajak penghasilan mereka karena mereka merasa beban pajak penghasilan yang besar akan mengurangi keuntungan mereka (Noor et al., 2010). Perusahaan akan berusaha mengelola pembayaran pajaknya seminimum mungkin agar laba yang diperoleh maksimal (Darmawan dan Sukartha, 2014).

Tax avoidance merupakan salah satu upaya meminimalisir beban pajak yang sering dilakukan oleh perusahaan, sehingga menjadi suatu persoalan yang rumit dan menarik untuk diteliti. Tax avoidance ini bersifat legal karena masih berada dalam serangkaian peraturan perpajakan yang berlaku. Penghindaran pajak (tax avoidance) merupakan manipulasi penghasilan untuk meminimalisir jumlah pajak yang terhutang secara legal karena masih sesuai dengan ketentuan peraturan perundang-undangan perpajakan (Dwiyanti \& Jati, 2019).

Fenomena tax avoidance banyak dilakukan di dalam maupun di luar negeri. Salah satu contoh di luar negeri adalah perusahaan Google (cnbcindonesia.com, 2019). Raksasa teknologi asal Amerika Serikat (AS) Google dilaporkan melakukan tax avoidance senilai 19,9 miliar euro (US\$ 22,7 Miliar atau setara Rp 317 triliun) melalui sebuah perusahaan cangkang Belanda ke Bermuda pada tahun 2017. Praktik tax avoidance juga terjadi di Indonesia yakni tax avoidance yang dilakukan oleh PT. Adaro Energy Tbk. Direktorat Jenderal Pajak (DJP) mendalami dugaan tax avoidance yang dilakukan oleh perusahaan batu bara PT. Adaro Energy Tbk dengan skema transfer pricing melalui anak perusahaan yang berada di Singapura (www.tirto.id,2019). Global Witness menguraikan bagaimana Adaro mengurangi jumlah pajak yang seharusnya mereka bayarkan di Indonesia. Global Witness menyebut sejak 2009 hingga 2017, Adaro membayar pajak US\$125 juta lebih rendah kepada pemerintah Indonesia.

Dari berbagai fenomena yang terjadi, tax avoidance diindikasikan masih dilakukan oleh para Wajib Pajak. Dapat dilihat dari Tabel 1, realisasi penerimaan pajak pada tahun 2018 dan 2019 mengalami penurunan sebesar 8,01\% dari target APBN, berbanding terbalik jika dibandingkan dengan penerimaan pajak tahun 2017 dan 2018 yang mengalami kenaikan sebesar 1,21\% (Kemenkeu.go.id). Tax avoidance yang dilakukan terus menerus akan mengurangi pendapatan negara secara tidak langsung. Tax avoidance merupakan usaha pengurangan pajak, namun 
tetap mematuhi ketentuan peraturan perpajakan seperti memanfaatkan pengecualian dan potongan yang diperkenankan maupun menunda pajak yang belum diatur dalam peraturan perpajakan yang berlaku dan biasanya melalui kebijakan yang diambil oleh pimpinan perusahaan (Dewinta \& Setiawan, 2016).

Tabel 1. Perbandingan Realisasi Penerimaan Pajak terhadap APBN

\begin{tabular}{lcccc}
\hline Keterangan & 2016 & 2017 & 2018 & 2019 \\
\hline APBN Penerimaan Pajak & $\operatorname{Rp} 1.539 \mathrm{~T}$ & $\operatorname{Rp} 1.472 \mathrm{~T}$ & $\operatorname{Rp} 1.424 \mathrm{~T}$ & $\operatorname{Rp} 1.577 \mathrm{~T}$ \\
Realisasi & $\operatorname{Rp} 1.285 \mathrm{~T}$ & $\operatorname{Rp} 1.343 \mathrm{~T}$ & $\operatorname{Rp} 1.315 \mathrm{~T}$ & $\operatorname{Rp} 1.332 \mathrm{~T}$ \\
$\%$ terhadap target APBN & $83,50 \%$ & $91,20 \%$ & $92,41 \%$ & $84,40 \%$ \\
\hline
\end{tabular}

Sumber: Data Penelitian, 2021

Motivasi utama dilakukan penelitian ini agar penelitian ini dapat dijadikan referensi bagi penelitian selanjutnya dan menambah pengetahuan bagi peneliti maupun pembaca berkaitan dengan pengaruh intensitas persediaan, intensitas aset tetap, dan beban iklan terhadap tax avoidance dengan kepemilikan institusional sebagai variabel moderasi yang merupakan pengembangan dari penelitian terdahulu. Dari sudut pandang investor, penelitian ini diharapkan dapat menjadi bahan pertimbangan para investor untuk mengambil keputusan melakukan investasi dan memperoleh gambaran mengenai faktor-faktor apa saja yang dapat mempengaruhi tax avoidance. Masih banyaknya fenomena tax avoidance yang terjadi, maka sangat memotivasi peneliti untuk melakukan penelitian ini.

Penelitian ini merupakan replikasi penelitian dari beberapa penelitian terdahulu yang telah dilakukan antara lain oleh Romadhina (2019) dan Novitasari, Suharni (2019) dengan menambahkan kepemilikan institusional sebagai variabel moderating dan profitabilitas sebagai variabel kontrol dalam satu model penelitian untuk diteliti.

Noor et al. (2010), Novitasari \& Suharni (2019) serta Dwiyanti \& Jati (2019) dalam penelitian terdahulu menunjukkan bahwa intensitas persediaan berpengaruh positif terhadap tax avoidance. Manajer termotivasi untuk menaikkan pembelian persediaan karena adanya desakan untuk menurunkan biaya politik yang dimiliki oleh perusahaan. Selain dilihat dari intensitas persediaan, karakteristik suatu perusahaan juga tercermin dari intensitas aset tetapnya. Intensitas aset tetap mencerminkan bagaimana perusahaan tersebut menginvestasikan modal yang dimiliki dalam bentuk aset tetap.

Beban iklan merupakan suatu pengeluaran perusahaan yang digunakan untuk kegiatan promosi agar menarik minat konsumen dan memiliki tujuan sebagai pengurang laba perusahaan. Hal tersebut dilakukan dengan tujuan untuk mengurangi beban pajak perusahaan tersebut. Menurut penelitian terdahulu yang dilakukan oleh Mansi et al. (2019) menunjukkan bahwa beban iklan berpengaruh negatif terhadap tax avoidance. Namun, sejalan dengan penelitian terdahulu yang dilakukan oleh Fatmawati \& Solikin (2017), hasil penelitian menunjukkan bahwa beban iklan berpengaruh positif terhadap tax avoidance.

Adanya perbedaan hasil penelitian terhadap tax avoidance maka menimbulkan dugaan adanya variabel yang memoderasi hubungan antara intensitas persediaan, intesitas aset tetap dan beban iklan. Variabel yang diduga memoderasi hubungan tersebut adalah kepemilikan institusional. Berdasarkan teori keagenan, kepemilikan institusional memiliki peranan penting dalam 
meminimalisasi konflik keagenan yang timbul antara pemegang saham dan pengelola perusahaan (Jensen \& Meckling, 1976). Kepemilikan institusional merupakan investor yang aktif dalam melakukan monitoring terhadap manajemen karena investor institusi pada umumnya memiliki saham untuk jangka panjang. Secara rasional, kepemilikan institusional akan bertindak bagi kepentingan mereka, dan bukan dengan bijaksana dan adil bertindak demi kepentingan pemegang saham (Tjager et al., 2003).

Dengan adanya kepemilikan institusional dalam perusahaan, pemilik saham institusi akan melakukan intervensi terhadap manajemen untuk mengutamakan tingkat pengembalian yakni deviden sebesar-besarnya. Hasil penelitian terdahulu yang telah dilakukan oleh Ramadhani \& Azmi (2019) dan Prasetyo et al. (2018) dan Sonia \& Suparmun (2019) menunjukkan bahwa kepemilikan institusional berpengaruh positif terhadap tax avoidance. Dari uraian tersebut, maka penelitian ini menggunakan variabel tax avoidance sebagai variabel dependen, variabel intensitas persediaan, intensitas aset tetap dan beban iklan sebagai variabel independen, variabel kepemilikan insititusional sebagai variabel moderasi, serta variabel profitabilitas sebagai variabel kontrol dengan kerangka penelitian sebagai berikut.

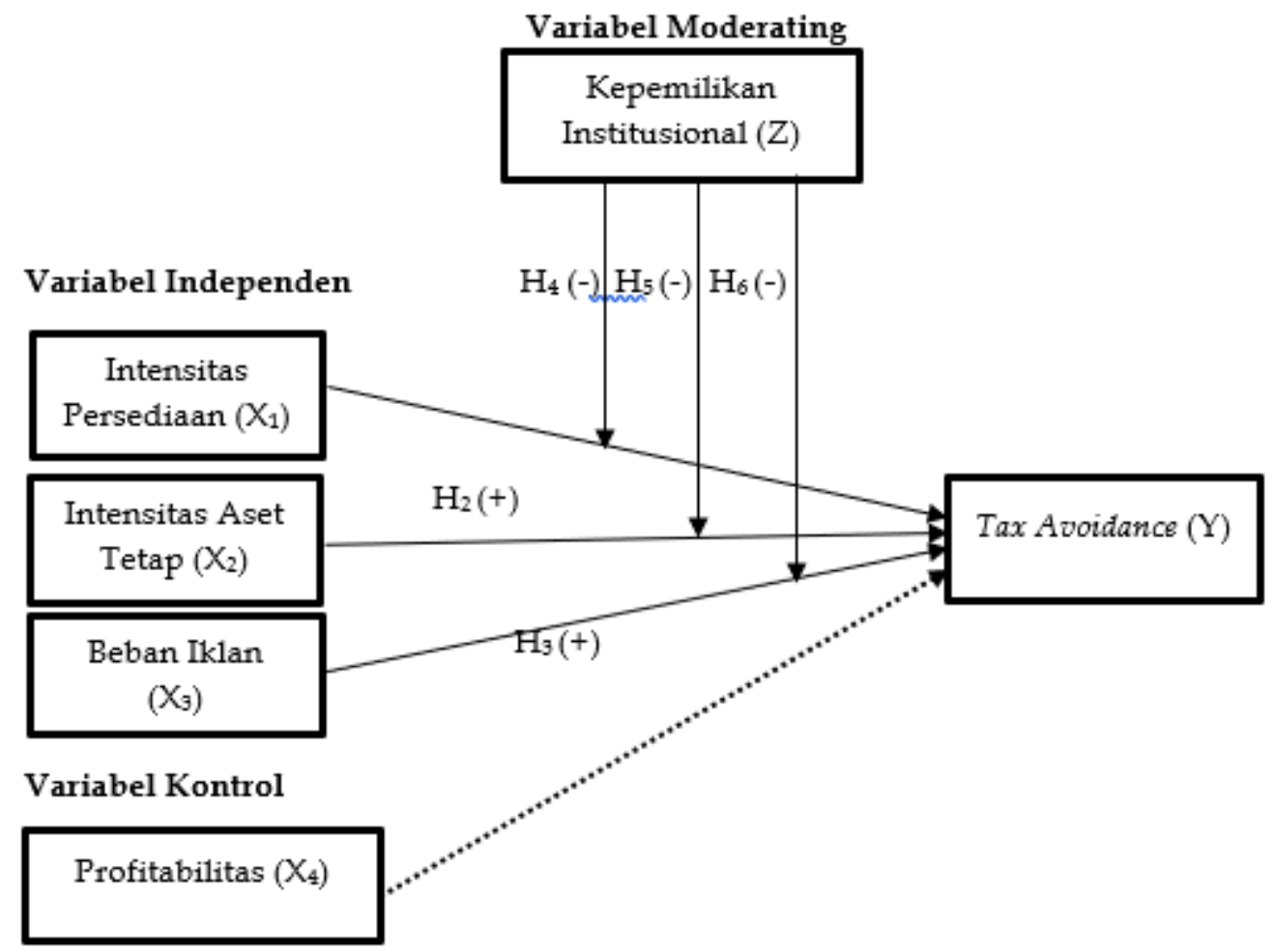

Sumber : Data Penelitian, 2021

\section{Gambar 1. Kerangka Pemikiran}

Berdasarkan teori akuntansi positif, manajemen memiliki kebebasan untuk memilih prosedur akuntansi yang ingin digunakan. Oleh karena itu, menajemen cenderung akan melakukan tindakan oportunistik (opportunistic behaviour)(Scott, 2015). Perusahaan dapat memilih memilih metode akuntansi yang menangguhkan laba yang diperoleh pada tahun sekarang (Watts \& Zimmerman, 1990). Dengan meningkatkan intensitas persediaan maka akan berdampak pada berkurangnya 
laba yang diperoleh oleh perusahaan. Oleh karena itu, peningkatan intensitas persediaan akan mempengaruhi jumlah pajak yang dibayarkan oleh perusahaan. Beberapa penelitian terdahulu mengenai intensitas persediaan telah dilakukan oleh Noor et al. (2010), Novitasari \& Suharni (2019) serta Dwiyanti \& Jati (2019) yang menunjukkan bahwa intensitas persediaan berpengaruh positif terhadap tax avoidance. Keinginan para manajer untuk menaikkan pembelian persediaan semakin meningkat karena adanya desakan untuk menurunkan biaya politik yang dimiliki oleh perusahaan.

Adanya peningkatan intensitas persediaan tersebut maka biaya yang dikeluarkan oleh perusahaan terkait dengan persediaan akan meningkat. Dengan adanya faktor - faktor pengurang seperti biaya pengiriman barang dan biaya lainnya terkait dengan adanya pembelian persediaan barang tersebut (PSAK 14), maka beban pajak akan berkurang. Dengan adanya pengurangan laba, maka kesempatan perusahaan untuk melakukan tax avoidance semakin meningkat. Oleh karena itu, hipotesis pertama dalam penelitian ini sebagai berikut.

$\mathrm{H}_{1}$ : Intensitas persediaan berpengaruh positif terhadap tax avoidance.

Berdasarkan teori akuntansi positif, setiap perusahaan memiliki prosedur akuntansi yang berbeda satu sama lain. Perusahaan dapat dengan bebas menentukan kebijakan akuntansi yang dapat meminimalisir biaya politik yang dimiliki (Watts \& Zimmerman, 1990). Perusahaan dengan jumlah aset yang besar akan memiliki beban pajak yang lebih rendah jika dibandingkan dengan perusahaan yang memiliki jumlah aset yang lebih kecil. Perusahaan akan mendapatkan keuntungan dari beban depresiasi yang ditanggung oleh perusahaan.

Sejalan dengan penelitian yang dilakukan oleh Muzakki \& Darsono (2015), Razif \& Vidamaya (2017), Dwiyanti \& Jati (2019) serta Ardyansah \& Zulaikha (2014) yang menyimpulkan bahwa intensitas aset tetap berpengaruh positif terhadap tax avoidance. Aset merupakan semua kekayaan yang dimiliki oleh seorang atau perusahaan baik berwujud maupun tak berwujud, baik yang berharga maupun tidak, dimana akan mendatangkan manfaat bagi seseorang atau perusahaan yang memilinya (PSAK 16, 2014). Oleh karena itu, aset tetap akan memungkinkan perusahaan untuk mengurangi pajaknya akibat dari biaya penyusutan yang dimiliki oleh aset tetap tersebut tiap tahunnya dan akan berpengaruh sebagai pengurang beban pajak. Oleh karena itu, hipotesis kedua dalam penelitian ini sebagai berikut.

$\mathrm{H}_{2}$ : Intensitas aset tetap berpengaruh positif terhadap tax avoidance.

Dalam political cost hypothesis, manajer akan berusaha untuk menurunkan biaya politik yang mereka miliki dengan cara memilih prosedur akuntansi yang menangguhkan laba periode sekarang menjadi laba periode yang akan datang. Perusahaan memiliki kebebasan untuk memilih kebijakan akuntansi yang menguntungkan dan memaksimumkan kepuasan perusahaan tersebut (Scott, 2015). Dengan menaikkan beban iklan, perusahaan dapat mempromosikan citra mereka dan sekaligus menambah beban perusahaan, dimana beban perusahaan tersebut akan mengurangi laba perusahaan. Oleh karena itu, beban iklan dianggap sebagai faktor yang dapat mempengaruhi tax avoidance.

Penelitian terdahulu yang telah dilakukan oleh Mansi et al. (2019) menunjukkan bahwa beban iklan berpengaruh negatif terhadap tax avoidance. 
Penelitian selanjutnya juga dilakukan oleh Novitasari \& Suharni (2019) dan Pratiwi et al. (2017) menunjukkan bahwa beban iklan tidak berpengaruh terhadap tax avoidance. Namun, sejalan dengan penelitian terdahulu yang dilakukan oleh Fatmawati \& Solikin (2017), hasil penelitian menunjukkan bahwa beban iklan berpengaruh positif terhadap tax avoidance. Sesuai PMK Nomor 2/PKM.03/2010 pasal 2, biaya iklan dapat dikurangkan dari penghasilan bruto meliputi biaya periklanan di media elektronik, media cetak, biaya pameran produk, biaya pengenalan produk baru dan biaya sponshorship, biaya tersebut dapat mengurangi tanggungan pajak perusahaan. Perusahaan yang memiliki beban iklan yang besar, maka laba perusahaan yang dimiliki semakin rendah. Adanya beban iklan akan memungkinkan manajemen untuk melakukan tax avoidance. Oleh karena itu, hipotesis ketiga dalam penelitian ini sebagai berikut.

$\mathrm{H}_{3}$ : Beban iklan berpengaruh positif terhadap tax avoidance.

Berdasarkan teori keagenan, kepemilikan institusional memiliki peranan penting dalam meminimalisasi konflik keagenan yang timbul antara pemegang saham dan pengelola perusahaan (Jensen \& Meckling, 1976). Kepemilikan institusional merupakan salah satu mekanisme pengawasan untuk mengatasi masalah keagenan (Fama \& Jensen, 1983). Kepemilikan institusional sangat berperan dalam mengawasi perilaku para manajer dan memaksa manajer untuk lebih waspada dalam mengambil keputusan oportunistik (Listyani, 2003).

Adanya aktivitas pemegang saham yang lebih besar dari pemilik saham institusi akan membantu meningkatkan tax avoidance demi kepentingan pemegang saham dimana pemegang saham yang lebih besar akan melakukan intervensi terhadap manajemen perusahaan untuk meminimalisir jumlah pajak perusahaan dan meningkatkan kekayaan mereka sendiri. Sejalan dengan penelitian yang dilakukan oleh Ramadhani \& Azmi (2019), Prasetyo et al. (2018) dan Sonia \& Suparmun (2019), hasil penelitian menunjukkan bahwa kepemilikan institusional berpengaruh positif terhadap tax avoidance.

Tingginya peran dari pemilik saham institusi akan meningkatkan pengendalian terhadap manajemen dalam pengambilan keputusan untuk melakukan pembelian persediaan yang over stock. Para pemegang saham tentunya mengharapkan persediaan yang dimiliki memiliki rasio perputaran yang baik agar tidak menimbulkan biaya tambahan seperti biaya penyimpanan, penanganan dan lainnya. Dengan adanya peran dari pemilik saham institusi maka tingkat pengawasan terhadap manajer semakin besar dan dapat mengurangi konflik kepentingan yang terjadi sehingga masalah keagenan akan berkurang dan mengurangi peluang terjadinya tax avoidance. Oleh karena itu, hipotesis keempat dalam penelitian ini sebagai berikut.

$\mathrm{H}_{4}$ : Kepemilikan institusional memperlemah pengaruh positif intensitas persediaan terhadap tax xvoidance.

Teori keagenan menyatakan bahwa adanya perbedaan kepentingan antara prinsipal dan agen akan menimbulkan asimetri informasi (Jensen \& Meckling, 1976). Keberadaan kepemilikan institusional dalam perusahaan bertugas mengawasi segala tindakan manajemen perusahaan agar terhindar dari ketentuan yang tidak benar. Kepemilikan institusional akan mencegah terjadinya fraud oleh perusahaan. Keberadaan kepemilikan institusional sebagai elemen corporate governance merupakan sarana untuk mengawasi manajemen dari tindakan 
oportunistik yang dapat dilakukan manajer seperti melakukan aktivitas tax avoidance (Olivia \& Dwimulyani, 2019).

Sejalan dengan penelitian yang dilakukan oleh Ramadhani \& Azmi (2019), Prasetyo et al. (2018) dan Sonia \& Suparmun (2019), hasil penelitian menunjukkan bahwa kepemilikan institusional berpengaruh positif terhadap tax avoidance. Dengan adanya peran dari pemilik saham institusi, pengendalian manajemen akan semakin meningkat. Pemilik saham institusi akan lebih cenderung melakukan pembelanjaan aset untuk ekspansi usaha saja, bukan untuk melakukan tax avoidance. Pemilik saham institusi sebagai investor lebih mengutamakan tingkat pengembalian yang sebesar-besarnya atas investasi yang mereka berikan berupa deviden. Oleh karena itu, hipotesis kelima dalam penelitian ini adalah:

$\mathrm{H}_{5}$ : Kepemilikan institusional memperlemah pengaruh positif intensitas aset tetap terhadap tax avoidance.

Teori agensi menjelaskan bahwa adanya asimetri informasi yang timbul karena perbedaan kepentingan antara pihak prinsipal dan agen (Jensen \& Meckling, 1976). Bagi perusahaan sebagai agen, penggunaan iklan sangat berguna untuk memasarkan produk yang dijual oleh perusahaan tersebut. Biaya iklan yang muncul akan menjadi pengurang beban pajak perusahaan. Bagi lembaga institusional sebagai prinsipal, beban iklan yang timbul akan mengurangi tingkat pengembalian yang akan mereka dapatkan. Berdasarkan penelitian terdahulu yang sudah dilakukan, penelitian yang dilakukan oleh Ramadhani \& Azmi (2019), Prasetyo et al. (2018) dan Sonia \& Suparmun (2019), hasil penelitian menunjukkan bahwa kepemilikan institusional berpengaruh positif terhadap tax avoidance. Beban iklan digunakan oleh perusahaan untuk memasarkan citra produk yang dimiliki oleh mereka. Para pemilik saham dari lembaga institusi keuangan lebih mengutamakan tingkat pengembalian berupa deviden. Mereka akan lebih berhatihati dalam memilah pengeluaran operasional yang sebaiknya dikeluarkan untuk memasarkan citra produk mereka. Oleh karena itu, hipotesis keenam dalam penelitian ini sebagai berikut.

$\mathrm{H}_{6}$ : Kepemilikan institusional memperlemah pengaruh positif beban iklan terhadap tax avoidance.

\section{METODE PENELITIAN}

Populasi dalam penelitian ini adalah seluruh perusahaan yang termasuk dalam sektor barang konsumen primer berdasarkan data IDX - IC yang terdaftar di Bursa Efek Indonesia dalam rentang waktu 2016 hingga 2019. Alasan pemilihan sampel mulai tahun 2016 hingga 2019 dikarenakan adanya penurunan penerimaan pajak oleh negara jika dibandingkan dengan tahun sebelumnya. Selain itu, karena adanya amnesti pajak pada tahun 2016 dan Dirjen Pajak menganggap tahun 2015 sebagai dasar patokan untuk pelaporan amnesti pajak maka tahun 2016 dipilih sebagai permulaan tahun pemilihan sampel.

Objek penelitian yang digunakan dalam penelitian ini adalah intensitas persediaan $\left(\mathrm{X}_{1}\right)$, intensitas aset tetap $\left(\mathrm{X}_{2}\right)$, beban iklan $\left(\mathrm{X}_{3}\right)$ dan Tax Avoidance $(\mathrm{Y})$ pada perusahaan sektor konsumen primer yang terdaftar di IDX - IC tahun 2016 2019. Teknik yang digunakan untuk pengambilan sampel dalam penelitian ini dengan metode non-probability sampling, khususnya dengan cara purposive sampling. 
Variabel dependen dalam penelitian ini yaitu tax avoidance. Pada penelitian ini, proksi tax avoidance menggunakan pendekatan BBM (Benchmark Behavioral Model). Benchmark Behavioral Model disusun dengan membandingkan kinerja keuangan Wajib Pajak Badan dengan kinerja keuangan kelompok Wajib Pajak Badan sejenis, yaitu Wajib Pajak Badan yang berada pada klasifikasi usaha yang sama, terdaftar pada wilayah yang sama serta dalam rentang skala usaha yang sama (perpajakan.ddtc.co.id, 2016). Kinerja keuangan yang dimaksud disusun dalam rasio keuangan yang bersumber dari Surat Pemberitahuan (SPT) Tahunan Wajib Pajak Badan.

Berdasarkan pendekatan Benchmark Behavioral Model, maka proksi tax avoidance dalam penelitian ini mengikuti Goh et al. (2016), SE-02/PJ/2016 dan Trisnawati \& Budiono (2019) dan diukur dengan menggunakan operasionalisasi sebagai berikut.

Gross Profit Margin (GPM) $=-1 \times$ (gross profit/sales)

Operating Profit Margin (OPM) $=-1 \times$ (operating income/sales).

Pre-tax Profit Margin (PPM) $=-1 \times$ (net income before tax/sales)

Corporate Tax to Turn Over Ratio (CTTOR) $=-1 \times($ income tax $/$ sales $)$.

Net Profit Margin (NPM) $=-1 \times$ (net income/sales)....

Variabel independen dalam penelitian ini adalah intensitas persediaan, intensitas aset tetap dan beban iklan. Proksi pengukuran intensitas persediaan dalam penelitian ini mengikuti Romadhina (2019), Novitasari \& Suharni (2015), Jessica \& Toly (2014) dan Noor et al. (2010) yaitu dengan membandingkan nilai persediaan dengan nilai total aset yang dimiliki oleh perusahaan. Intensitas aset tetap menggambarkan proporsi aset tetap perusahaan pada keseluruhan aset yang dimiliki sebuah perusahaan. Proksi pengukuran intensitas aset tetap dalam penelitian ini mengikuti Noor et al. (2010), Ardyansah \& Zulaikha (2014), Irianto et al. (2017) dan Pratiwi et al. (2020) yaitu dengan membandingkan nilai aset tetap yang dimiliki dengan nilai total aset yang dimiliki oleh perusahaan.

Beban iklan merupakan beban yang dikeluarkan oleh perusahaan sehubungan dengan semua kegiatan yang dilakukan untuk mempromosikan dan memasarkan produk untuk dipasarkan kepada masyarakat luas. Proksi beban iklan perusahaan dalam penelitian ini mengikuti Nguyen (2015), Romadhina (2019), Fatmawati \& Solikin (2017) dan Novitasari \& Suharni (2019) akan diukur dengan cara membandingkan nilai beban iklan dengan nilai penjualan perusahaan tersebut. Variabel moderasi dalam penelitian ini adalah kepemilikan institusional. Kepemilikan institusional merupakan jumlah saham perusahaan yang dimiliki oleh pihak institusi atau lembaga. Kepemilikan institusional dapat diukur dengan cara membagi saham yang dimiliki oleh institusi dengan total saham keseluruhan (Tandean \& Winnie, 2016).

Penelitian menggunakan teknik analisis data dengan menggunakan software WarpPLS versi 7.0. Terdapat tiga algoritma di dalam analisis WarpPLS, yaitu algoritma pendugaan outer model, inner model, dan pengujian hipotesis (Kock, 2013). Outer Model menentukan spesifikasi hubungan antara konstruk laten dengan indikatornya (Sofyan et al.,2009). Outer model terdiri dari convergent validity, discriminant validity dan composite reliability. Inner Model menentukan spesifikasi hubungan antara konstrak laten dan konstrak laten lainnya (Sofyan et al.,2009). Evaluasi model struktural (inner model) meliputi uji kecocokan model (fit model), 
path coefficient dan $\mathrm{R}^{2}$. Uji hipotesis digunakan untuk menjelaskan arah hubungan antara variabel independen dan variabel dependennya. Model analisis yang digunakan dalam penelitian ini adalah Moderated Regression Analysis (MRA). Model analisis ini digunakan dengan tujuan untuk mengetahui apakah variabel kepemilikan institusional dapat memperkuat atau memperlemah pengaruh intensitas persediaan, intensitas aset tetap dan beban iklan terhadap tax avoidance pada perusahaan sektor barang konsumen primer tahun 2016 - 2019. Model MRA dalam penelitian ini sebagai berikut.

TAvoid $=a+b_{1}$ INTINV $_{i t}+b_{2}$ INTAT $_{i t}+b_{3}$ Advertise $_{i t}+b_{4}$ ROAit $_{+}$ $b_{5} I N T I V T * O S_{i t}+b_{6} I N T A T * O S_{i t}+b_{7}$ Advertise $* O S_{i t}+\varepsilon_{i t}$

Keterangan:

TAvoid = Proksi untuk mengukur tax avoidance perusahaan tahun $\mathrm{t}$

a $\quad$ Konstanta

$b_{1}, b_{2} \quad=$ Koefisien regresi

INTINV $_{\text {it }} \quad=$ Intensitas Persediaan perusahaan i tahun $\mathrm{t}$

$\operatorname{INTAT}_{\text {it }} \quad=$ Intensitas Aset Tetap perusahaan $\mathrm{i}$ tahun $\mathrm{t}$

Advertise $_{i t}=$ Beban Iklan perusahaan i tahun $\mathrm{t}$

$R_{O A} \quad=$ Profitabilitas perusahaan i tahun $\mathrm{t}$

$O S_{i t} \quad=$ Kepemilikan perusahaan $\mathrm{i}$ tahun $\mathrm{t}$

\section{HASIL DAN PEMBAHASAN}

Perusahaan sektor barang konsumen primer yang terdaftar di Bursa Efek Indonesia periode 2016 - 2019 berjumlah 89 perusahaan. Pengambilan sampel pada penelitian ini menggunakan metode purposive sampling, yakni menggunakan kriteria tertentu dalam menentukan sampel yang akan digunakan. Hasil dari pemilihan sampel disajikan pada Tabel 2.

\section{Tabel 2. Kriteria Pemilihan Sampel}

\begin{tabular}{clc}
\hline No. & \multicolumn{1}{c}{ Keterangan } & Jumlah \\
\hline 1 & Perusahaan manufaktur sektor barang konsumen primer (kode D) & 89 \\
& yang terdaftar di BEI tahun 2016 - 2019 & \\
2 & Perusahaan telah melakukan IPO sebelum 1 Januari 2016 & $(28)$ \\
3 & Perusahaan melaporkan Lap. Keu secara terus menerus & $(6)$ \\
4 & Perusahaan memiliki nilai laba sebelum pajak positif & $(18)$ \\
5 & Perusahaan yang memiliki data tidak lengkap & $(2)$ \\
& Jumlah sampel yang digunakan dalam penelitian & 35 \\
& Periode penelitian & 4 tahun \\
& Jumlah sampel 2016-2019 & 140 \\
\hline
\end{tabular}

Sumber: Data Penelitian, 2021

Dalam penelitian ini, analisis statistik deskriptif yang digunakan adalah mean, minimum, dan maximum. Berdasarkan hasil uji statistik deskriptif diperoleh sebanyak 140 data observasi yang berasal dari 4 tahun yakni tahun 2016 - 2019 dengan jumlah sebanyak 35 perusahaan. Berdasarkan Tabel 3 dapat dilihat bahwa nilai rata - rata (mean) variabel tax avoidance sebesar -0,126. Nilai median dan standar deviasi dari variabel tax avoidance adalah 0,196 dan 0,136. Nilai maximum dari tax avoidance adalah 0,066 yang diperoleh dari perusahaan Sampoerna Agro Tbk. (SGRO) tahun 2016 dengan proksi CTTOR. Nilai minimum dari tax avoidance adalah -0,738 yang diperoleh dari perusahaan Delta Djakarta Tbk. (DLTA) tahun 
2017 dengan proksi GPM. Variabel intensitas persediaan dinyatakan dalam rasio antara nilai persediaan yang dimiliki oleh perusahaan dibandingkan dengan nilai total aset yang dimiliki perusahaan tersebut. Berdasarkan Tabel 3 dapat dilihat bahwa nilai rata - rata dari variabel intensitas persediaan (INTINVT) sebesar 0,219 . Nilai median dan standar deviasi dari variabel intensitas persediaan adalah $-0,192$ dan 0,226. Nilai maximum dari INTINVT adalah 2,135 yang diperoleh dari perusahaan Wismilak Inti Makmur Tbk. (WIIM) tahun 2017. Nilai minimum dari INTINVT adalah 0,011 yang diperoleh dari perusahaan Nippon Indosari Corpindo Tbk. (ROTI) tahun 2017.

Tabel 3. Statistik Deskriptif

\begin{tabular}{cccccc}
\hline & INTINVT & INTAT & ADV & PROF_ROA & TAVOID \\
\hline Min & 0,011 & 0,027 & 0,000 & 0,000 & $-0,738$ \\
Max & 2,135 & 3,917 & 0,208 & 1,262 & 0,066 \\
Mean & 0,219 & 0,398 & 0,029 & 0,106 & $-0,126$ \\
Median & $-0,192$ & $-0,146$ & $-0,562$ & $-0,256$ & 0,196 \\
Std. Dev & 0,226 & 0,419 & 0,044 & 0,140 & 0,136 \\
\hline
\end{tabular}

Sumber: Data Penelitian, 2021

Variabel intensitas aset tetap dinyatakan dengan rasio antara nilai aset tetap yang dimiliki oleh perusahaan dibandingkan dengan nilai total aset yang dimiliki perusahaan tersebut. Berdasarkan Tabel 3 dapat dilihat bahwa nilai rata rata dari variabel intensitas aset tetap (INTAT) sebesar 0,398. Nilai median dan standar deviasi dari variabel intensitas asset tetap adalah -0,146 dan 0,419. Nilai maximum dari INTAT adalah 3,917 yang diperoleh dari perusahaan Wismilak Inti Makmur Tbk. (WIIM) tahun 2017. Nilai minimum dari INTAT adalah 0,027 yang diperoleh dari perusahaan Tigaraksa Satria Tbk. (TGKA) tahun 2018. Variabel beban iklan dinyatakan dengan rasio antara beban iklan yang dikeluarkan oleh perusahaan dibandingkan dengan nilai penjualan yang dimiliki perusahaan tersebut.

Nilai rata - rata dari variabel beban iklan yang dimiliki sebesar 0,029. Nilai median dan standar deviasi dari variabel beban iklan adalah -0,562 dan 0,044. Nilai maximum dari ADV adalah 0,208 yang diperoleh dari perusahaan Kino Indonesia Tbk. (KINO) tahun 2018. Nilai minimum dari ADV adalah 0,000. Langkah selanjutnya dalam penelitian ini adalah evaluasi outer model yang dilakukan melalui 3 kriteria yakni convergent validity, discriminant validity dan composite reliability. Hasil pengolahan data penelitian dengan evaluasi outer model dijelaskan dalam Tabel 4.

Berdasarkan pengolahan data penelitian menunjukkan bahwa pada variabel independen dan dependen pada penelitian ini memenuhi outer model karena variabel dalam penelitian ini memiliki faktor loading $>0,70$ (Yamin \& Kurniawan, 2011). Jika variabel dalam penelitian memiliki nilai faktor loading lebih kecil dari 0,40, maka variabel tersebut harus dihapus untuk meningkatkan nilai Average Variance Extracted (AVE) dan composite reliability (Yamin \& Kurniawan, 2011). Dalam penelitian tidak ada variabel yang memiliki nilai faktor loading lebih kecil dari 0,40 , maka tidak ada variabel yang perlu dihapus. 
Nilai AVE pada Tabel 4 dalam penelitian ini lebih besar dari 0,50, maka data dalam penelitian ini dapat dikatakan telah memenuhi uji discriminant validity. Nilai composite reliability dalam penelitian ini lebih besar dari 0,70, maka outer model dapat diterima (Yamin \& Kurniawan, 2011).

Tabel 4. Hasil Output Evaluasi Outer Model

\begin{tabular}{|c|c|c|c|c|c|c|}
\hline No & Var & \multicolumn{2}{|c|}{ Dimensi } & $\begin{array}{l}\text { Faktor } \\
\text { Loading }\end{array}$ & AVE & $\mathrm{CR}$ \\
\hline 1 & INTINVT & $\mathrm{X} 1$ & INTINVT & 1,000 & 1,000 & 1,000 \\
\hline 2 & INTAT & $\mathrm{X} 2$ & INTAT & 1,000 & 1,000 & 1,000 \\
\hline 3 & ADV & $\mathrm{X} 3$ & ADV & 1,000 & 1,000 & 1,000 \\
\hline 4 & PROF_ROA & CONTROL & ROA & 1,000 & 1,000 & 1,000 \\
\hline 5 & OS & MODERASI & OS & 1,000 & 1,000 & 1,000 \\
\hline 6 & INTINVT_OS & & ININVT*OS & 1,000 & 1,000 & 1,000 \\
\hline 7 & INTAT_OS & & INTAT*OS & 1,000 & 1,000 & 1,000 \\
\hline \multirow[t]{3}{*}{8} & ADV_OS & & $\mathrm{ADV}^{*} \mathrm{OS}$ & 1,000 & 1,000 & 1,000 \\
\hline & & & GPM & 0,848 & & \\
\hline & & & OPM & 0,979 & & \\
\hline \multirow[t]{3}{*}{9} & TAVOID & Y & PPM & 0,989 & 0,946 & 0,970 \\
\hline & & & CTTOR & 0,939 & & \\
\hline & & & NPM & 0,969 & & \\
\hline
\end{tabular}

Sumber: Data Penelitian, 2021

Tahap penelitian selanjutnya adalah melakukan evaluasi model struktural (inner model) yang meliputi uji kecocokan model (fit model), path coefficient, dan R².

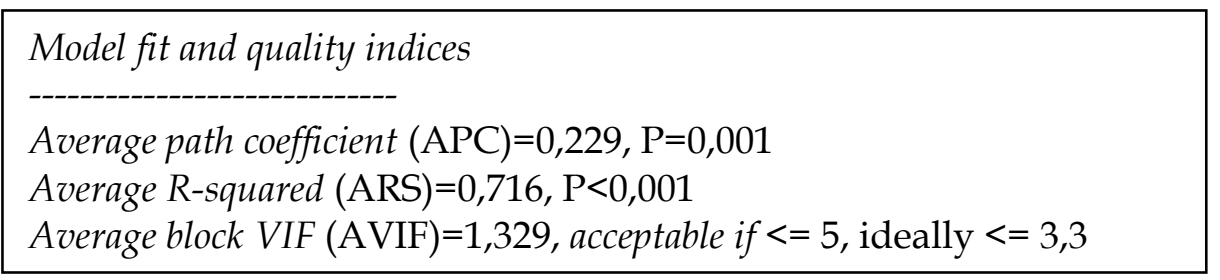

Sumber: Data Penelitian, 2021

Gambar 2. Model Fit and Quality Indices

Hasil output pada gambar 2 menjelaskan bahwa APC memiliki indeks sebesar 0,229 dengan nilai p-value 0,001. Oleh karena itu, APC sudah memenuhi kriteria karena memiliki nilai $\mathrm{p}<0,05$. ARS memiliki nilai indeks sebesar 0,716 dengan nilai $p$-value $<0,001$. Berdasarkan kriteria dalam penelitian inner model, maka ARS dapat dinyatakan valid dalam uji kecocokan model. Nilai AVIF dalam penelitian ini sebesar 1,329, maka sudah terpenuhi karena kriteria AVIF harus lebih kecil dari 5. Oleh karena itu, dapat dikatakan Evaluasi Model Struktural (inner model) dapat diterima.

Tabel 5. Uji Kecocokan Model

\begin{tabular}{ccccc}
\hline & Indeks & P-Value & Kriteria & Keterangan \\
\hline APC & 0,229 & $<0,001$ & $\mathrm{P}<0,05$ & Diterima \\
ARS & 0,716 & $<0,001$ & $\mathrm{P}<0,05$ & Diterima \\
AVIF & 1,329 & Good if $<5$ & AVIF $<5$ & Diterima \\
\hline
\end{tabular}

Sumber: Data Penelitian, 2021

Pengujian hipotesis ini dimaksudkan untuk membuktikan kebenaran dugaan penelitian atau hipotesis. Hasil korelasi antar konstruk diukur dengan 
melihat path coefficients dan tingkat signifikansinya, lalu dibandingkan dengan hipotesis penelitian yang terdaftar di bab sebelumnya. Tingkat signifikansi yang dipakai dalam penelitian adalah sebesar $10 \%$. Berikut ini merupakan gambar model penelitian dan hasil dari effect size yang telah diperoleh berdasarkan pengolah data.

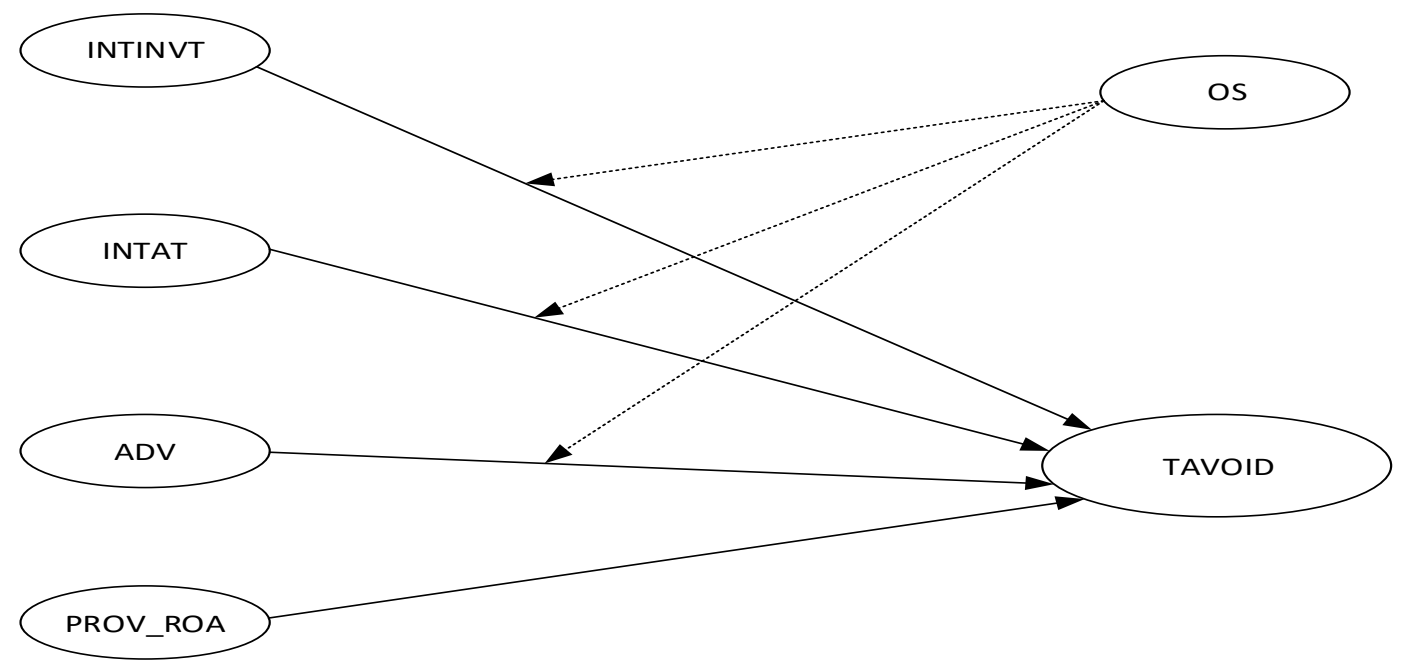

Sumber: Data Penelitian, 2021

\section{Gambar 3. Model Penelitian}

Keterangan:

INTINVT= Intensitas Persediaan

INTAT = Intensitas Aset Tetap

$A D V \quad=$ Beban Iklan

PROF_ROA = Profitabilitas

OS $\quad=$ Kepemilikan Institusional

TAVOID $=$ Tax Avoidance

Berdasarkan tabel 6, maka dapat disimpulkan bahwa dengan tingkat signifikansi $5 \%$, intensitas persediaan, intensitas aset tetap dan beban iklan memiliki pengaruh signifikan terhadap tax avoidance. Jika menggunakan tingkat signifikansi $10 \%$ dan ditambahkannya pemoderasi, maka kepemilikan institusional dapat memoderasi intensitas aset tetap terhadap tax avoidance dengan nilai $p$-values sebesar 0,028 .

Tabel 6. Hasil Pengujian Hipotesis

\begin{tabular}{lcccc}
\hline Hubungan Antar Variabel & $\begin{array}{c}R- \\
\text { squared }\end{array}$ & $\begin{array}{c}\text { Adj. } R \text { - } \\
\text { squared }\end{array}$ & $p$-values & $\begin{array}{c}\text { Nilai } \\
\text { Beta }\end{array}$ \\
\hline Intensitas Persediaan -> Tax Avoidance & & & $<0,01$ & 0,407 \\
Intensitas Aset Tetap -> Tax Avoidance & & & 0,031 & 0,154 \\
Beban Iklan -> Tax Avoidance & & & 0,016 & 0,175 \\
Intensitas PersediaanKepemilikan & 0,72 & 0,701 & 0,168 & 0,080 \\
Institusional -> Tax Avoidance & & & 0,028 & 0,157 \\
Intensitas Aset Tetap*Kepemilikan & & & 0,409 & 0,019 \\
Institusional -> Tax Avoidance & & & \\
Beban Iklan*Kepemilikan Institusional -> & & & \\
Tax Avoidance
\end{tabular}

Sumber : Data Penelitian, 2021 
Berdasarkan Gambar 3, nilai $\mathrm{R}^{2}$ dapat dilihat pada effect size, dimana nilainya sebesar 0,72 berarti bahwa variabel tax avoidance mempengaruhi variabel intensitas persediaan, intensitas aset tetap dan beban iklan sebesar $72 \%$ dan sisanya $28 \%$ dipengaruhi oleh variabel lainnya di luar penelitian ini. Hipotesis pertama dalam penelitian ini menunjukkan bahwa intensitas persediaan berpengaruh positif terhadap tax avoidance. Hasil penelitian ini sejalan dengan penelitian yang telah dilakukan oleh Noor et al. (2010), Novitasari \& Suharni (2019) serta Dwiyanti \& Jati (2019). Intensitas persediaan berpengaruh positif terhadap tax avoidance berarti besar kecilnya intensitas persediaan yang dimiliki dalam suatu perusahaan dapat mempengaruhi besar kecilnya jumlah pajak yang dibayarkan oleh perusahaan tersebut. Keinginan para manager cenderung untuk menaikkan pembelian persediaan semakin meningkat karena adanya desakan untuk menurunkan biaya politik yang dimiliki oleh perusahan. Dengan adanya peningkatan persediaan, maka akan timbul biaya - biaya pengurang yang diakibatkan dari peningkatan persediaan tersebut yang mana akan menyebabkan berkurangnya laba perusahaan. Hal tersebut akan meningkatkan kesempatan perusahaan untuk melakukan tax avoidance.

Hipotesis kedua dalam penelitian ini menunjukkan bahwa intensitas aset tetap berpengaruh positif terhadap tax avoidance. Hasil penelitian ini sejalan dengan penelitian yang dilakukan oleh penelitian Muzakki \& Darsono (2015), Razif \& Vidamaya (2017), Dwiyanti \& Jati (2019) serta Ardyansah \& Zulaikha (2014). Intensitas aset tetap berpengaruh terhadap tax avoidance, maka besar kecilnya intensitas aset tetap yang dimiliki oleh perusahaan berpengaruh terhadap tax avoidance. Jika ada pembelian aset tetap yang menyebabkan bertambahnya biaya penyusutan, maka akan berpengaruh terhadap tax avoidance.

Hipotesis ketiga dalam penelitian ini menunjukkan bahwa beban iklan berpengaruh negatif terhadap tax avoidance. Hasil penelitian ini sejalan dengan penelitian yang dilakukan oleh Romadhina (2019) dan berlawanan dengan penelitian yang dilakukan oleh Fatmawati \& Solikin (2017). Beban iklan berpengaruh terhadap tax avoidance, maka besar kecilnya beban iklan yang dimiliki oleh perusahaan dapat mempengaruhi tingkat tax avoidance yang dilakukan oleh perusahaan tersebut. Semakin tinggi intensitas iklan sebuah perusahaan, maka semakin rendah kecenderungan sebuah perusahaan untuk melakukan penghindaran pajak secara agresif. Hal ini disebabkan perusahaan tersebut lebih responsif terhadap citranya. Reputasinya di hadapan publik atau petugas pajak akan rusak apabila perusahaan mengambil risiko untuk melakukan tax avoidance.

Hipotesis keempat dalam penelitian ini menunjukkan bahwa kepemilikan institusional tidak dapat memoderasi pengaruh positif intensitas persediaan terhadap tax avoidance. Hasil pengujian hipotesis ini dapat disesuaikan dengan hasil penelitian oleh Tandean \& Winnie (2016) yang menyatakan bahwa kepemilikan institusional tidak berpengaruh terhadap tax avoidance sehingga kepemilikan institusional ini tidak dapat digunakan sebagai pemoderasi untuk memperlemah pengaruh positif intensitas persediaan terhadap tax avoidance. Sementara itu, hasil pengujian hipotesis ini berlawanan dengan hasil penelitian Ramadhani \& Azmi (2019), Prasetyo et al. (2018) dan Sonia \& Suparmun (2019) yang menyatakan bahwa kepemilikan institusional berpengaruh positif terhadap 
tax avoidance. Kepemilikan institusional tidak memiliki fungsi pengawasan tindakan penghindaran pajak yang dilakukan oleh manajer melalui informasi intensitas persediaan perusahaan.

Hipotesis kelima dalam penelitian ini menunjukkan bahwa kepemilikan institusional dapat memperkuat pengaruh positif intensitas aset tetap terhadap tax avoidance. Hasil pengujian hipotesis ini dapat disesuaikan dengan hasil penelitian oleh Ramadhani \& Azmi (2019), Prasetyo et al. (2018) dan Sonia \& Suparmun (2019) yang menyatakan bahwa kepemilikan institusional berpengaruh positif terhadap tax avoidance sehingga kepemilikan institusional ini dapat digunakan sebagai moderasi untuk mempengaruhi positif intensitas aset tetap terhadap tax avoidance. Sementara itu, hasil pengujian hipotesis ini berlawanan dengan hasil penelitian Tandean \& Winnie (2016) yang menyatakan bahwa kepemilikan institusional tidak berpengaruh terhadap tax avoidance. Kepemilikan institusional menganggap bahwa tindakan penghindaran pajak merupakan tindakan yang menyelaraskan kepentingan mereka. Di sisi lain, informasi atas aset tetap yang digunakan oleh perusahaan merupakan informasi yang penting bagi pemilik saham institusional karena melalui penggunaan aset tetap, manajer dalam melakukan perencanaan pajak dengan mengurangi beban pajak perusahaan.

Hipotesis keenam dalam penelitian ini menunjukkan bahwa kepemilikan institusional tidak dapat memperlemah pengaruh positif beban iklan terhadap tax avoidance. Hasil pengujian hipotesis dapat disesuaikan dengan hasil penelitian oleh Tandean \& Winnie (2016) yang menyatakan bahwa kepemilikan institusional tidak berpengaruh terhadap tax avoidance. Sementara itu, hasil pengujian hipotesis ini berlawanan dengan penelitian yang dilakukan Ramadhani \& Azmi (2019), Prasetyo et al. (2018) dan (Sonia \& Suparmun, 2019) yang menyatakan bahwa kepemilikan institusional berpengaruh positif terhadap tax avoidance. Dalam persepsi pemilik saham institusi, beban iklan bukan menjadi fokus utama ketika manajer memiliki insentif untuk memanfaatkannya dalam melakukan penghindaran pajak. Pemilik saham institusi diduga lebih fokus terhadap biayabiaya lainnya yang mendukung kepentingan mereka apabila manajer melakukan penghindaran pajak.

\section{SIMPULAN}

Intensitas persediaan berpengaruh positif terhadap tax avoidance. Tinggi rendahnya intensitas persediaan yang dimiliki oleh suatu perusahaan tidak mempengaruhi keputusan perusahaan untuk melakukan praktit tax avoidance. Intensitas aset tetap berpengaruh positif terhadap tax avoidance. Semakin tinggi nilai intensitas aset tetap yang dimiliki oleh perusahaan maka semakin tinggi juga kemungkinan dilakukannya tax avoidance dalam perusahaan tersebut. Beban iklan berpengaruh negatif terhadap tax avoidance. Semakin tinggi nilai beban iklan yang dimiliki oleh perusahaan maka semakin rendah kemungkinan dilakukannya tax avoidance dalam perusahaan tersebut.

Kepemilikan institusional tidak dapat memoderasi pengaruh intensitas persediaan dan beban iklan terhadap tax avoidance. Kepemilikan institusional dapat memoderasi pengaruh intensitas aset tetap terhadap tax avoidance. Kepemilikan institusional dapat memperkuat pengaruh intensitas persediaan 
terhadap tax avoidance, bukan memperlemah pengaruh intensitas persediaan terhadap tax avoidance.

Penelitian ini memiliki keterbatasan seperti data yang digunakan hanya menggunakan data laporan keuangan dari sektor konsumen primer yang terdaftar di IDX-IC sehingga tidak dapat menggeneralisir data perusahaan lain. Selain itu, horison waktu yang digunakan dalam penelitian ini relatif singkat. Penelitian ini mengindikasikan bahwa otoritas pajak di Indonesia perlu memperhatikan informasi-informasi dalam laporan keuangan tertentu seperti persediaan dan aset tetap perusahaan dalam mengidentifikasi penghindaran pajak yang dilakukan oleh perusahaan.

Bagi peneliti selanjutnya diharapkan agar dapat mengembangkan penelitian terkait tax avoidance dengan menambahkan variabel lain yang memungkinkan untuk mempengaruhi praktit tax avoidance dan mengganti variabel moderasi dengan variabel lainnya selain kepemilikan institusional. Penelitian juga diharapkan dapat menggunakan indikator lebih banyak untuk mengukur tingkat tax avoidance agar penelitian memiliki kesimpulan lebih baik lagi. Penelitian selanjutnya diharapkan dapat memperpanjang periode penelitian yang diharapkan dapat menambah sampel untuk diteliti serta mengganti populasi penelitian.

\section{REFERENSI}

Darmawan, I. G., \& Sukartha, I. M. (2014). Pengaruh Penerapan Corporate Governance, Leverage, Return On Assets, Dan Ukuran Perusahaan Pada Penghindaran Pajak. E-Jurnal Akuntansi Universitas Udayana, 9.1, 143-161.

Dewinta, I., \& Setiawan, P. (2016). Pengaruh Ukuran Perusahaan, Umur Perusahaan, Profitabilitas, Leverage, Dan Pertumbuhan Penjualan Terhadap Tax Avoidance. E-Jurnal Akuntansi Universitas Udayana, 14(3), 1584-1615.

Dwiyanti, I. A. I., \& Jati, I. K. (2019). Pengaruh Profitabilitas, Capital Intensity, dan Inventory Intensity pada Penghindaran Pajak. E-Jurnal Akuntansi, 27, 2293. https://doi.org/10.24843/eja.2019.v27.i03.p24

Fama, E. F., \& Jensen, M. C. (1983). Separation of Ownership and Control. Journal of Law and Economics, 26, 301-325.

Goh, B. W., Lee, L., Lim, C. Y., \& Shevlin, T. . (2016). The Effect of Corporate Tax Avoidance on the Cost of Equity. The Accounting Review, 91.

Jensen, M. C., \& Meckling, W. H. (1976). BEHAVIOR, THEORY OF THE FIRM: MANAGERIAL STRUCTURE, AGENCY COSTS AND OWNERSHIP. Journal of Financial Economics 3, 305-360.

Listyani, T. (2003). KEpemilikan Manajerial, Kebijakan Hutang, Dan Pengaruhnya Terhadap Kepemilikan Saham Institusional (Studi pada Perusahaan Manufaktur di Bursa Efek Jakarta). In Maksi.

Muzakki, M. R., \& Darsono. (2015). Pengaruh Corporate Social Responsibility Dan Capital Intensity Terhadap Penghindaran Pajak. E-Jurnal Akuntansi, 4(3), 445452.

Noor, R. M., Fadzillah, N. S. M., \& Mastuki, N. (2010). Tax planning and corporate effective tax rates. CSSR 2010 - 2010 International Conference on Science and Social Research, Cssr, 1238-1242. https://doi.org/10.1109/CSSR.2010.5773726 Olivia, I., \& Dwimulyani, S. (2019). Pengaruh Thin Capitalization dan Profitabilitas 
terhadap Penghindaran Pajak dengan Kepemilikan Institusional Sebagai Variabel Moderasi. Prosiding Seminar Nasional Pakar Ke 2.

Romadhina, A. P. (2019). Pengaruh Beban Iklan Dan Intensitas Persediaan Terhadap Agresivitas Pajak. Journal of Economic and Management Scienties, 2(1), $1-13$.

Scott, W. R. (2015). Financial Accounting Theory (Seventh Ed). Pearson Canada Inc.

Sonia, S., \& Suparmun, H. (2019). Factors Influencing Tax Avoidance. 73, 238-243. https://doi.org/10.2991/aicar-18.2019.52

Tandean, V. A., \& Winnie, W. (2016). The Effect of Good Corporate Governance on Tax Avoidance: An Empirical Study on Manufacturing Companies Listed in IDX period 2010-2013. Asian Journal of Accounting Research, 1(1), 28-38. https:/ / doi.org/10.1108/ AJAR-2016-01-01-B004

Tjager, I. N. et al. (2003). Corporate Governance: Tantangan dan Kesempatan bagi Komunitas Bisnis Indonesia. Prenhallindo.

Trisnawati, E., Fenny, \& Budiono, H. (2020). Influence of Transfer Pricing, CEO Compensation, and Accounting Irregularities on Tax Aggressiveness. 439(Ticash 2019), 170-174. https:/ / doi.org/10.2991/assehr.k.200515.028

Watts, R. L., \& Zimmerman, J. L. (1990). Positive Accounting Theory: A Ten Year Perspective. The Accounting Review, 65, 131.

Yamin, S., \& Kurniawan, H. (2011). Generasi Baru Mengolah Data Penelitian dengan Partial Least Square Path Moeling. Salemba Infotek. 